Fidei: Jurnal Teologi Sistematika dan Praktika, Vol. 3, No. 2, Des. 2020

Fidei: Jurnal Teologi Sistematika dan Praktika

Terakreditasi No: 85/M/KPT/2020 (Sinta 4)

e-ISSN: $2621-8135$

http://www.stt-tawangmangu.ac.id/e-journal/index.php/fidei

p-ISSN: 2621-815

Vol. 3 No.2 (Des. 2020) hlm: 160-180

DOI: https://doi.org/10.34081/fidei.v3i2.132

\title{
Menjembatani Injil dan Budaya dalam Misi Melalui Metode Kontektualisasi
}

\author{
David Eko Setiawan \\ Sekolah Tinggi Teologi Tawangmangu, Indonesia \\ Email: davidekosetiawan14217@gmail.com
}

Diterima: 25 Mei 2020

Direvisi: 5 September 2020

Disetujui: 15 September 2020

\begin{abstract}
Abstrak
Perjumpaan injil dan budaya dalam misi ada kalanya menimbulkan ketegangan. Bahkan tidak sedikit muncul penolakan akibat kurang pekanya sang pewarta injil terhadap budaya dari masyarakat tertentu. Kepekaan tersebut perlu dibangun agar injil dapat dikomunikasi kepada mereka sesuai konteks budayanya masing-masing. Tujuannya adalah untuk mengurangi kesalahpahaman disampaikan. Melalui metode kontekstualisasi, diharapkan ketegangan dapat teratasi serta akan terbangun jembatan yang dapat menghubungkan injil dan budaya.

Rumusan masalah di dalam penelitian ini adalah bagaimanakah metode kontekstualisasi dapat menjembatani injil dan budaya dalam misi? Adapun Tujuan penelitian ini adalah untuk menjelaskan bagaimana metode kontektualisasi dapat menjembatani injil dan budaya dalam misi. Sedangkan metode yang dipakai oleh penulis adalah menggunakan literature reasech. Hasil dari penelitian menunjukkan bahwa metode kontekstualisasi dapat digunakan dalam menjembatani injil dan budaya dalam misi bahkan juga dapat mengurangi ketegangan antara injil dan budaya.
\end{abstract}

Kata-Kata Kunci: Budaya; Injil; Kontekstualisasi; Misi.

\section{Abstract}

Gospel and cultural encounters in missions sometimes cause tension. Not even a few rejection emerged due to lack of sensitivity of the evangelist to the culture of certain communities. That sensitivity needs to be built so that the 
gospel can be communicated to them according to their respective cultural contexts. The aim is to reduce misunderstandings conveyed. Through the contextualization method, it is hoped that tensions can be overcome and bridges will be built that can connect the gospel and culture.

The formulation of the problem in this research is how can the contextualization method bridge the gospel and culture in mission? The purpose of this study is to explain how the method of contextualization can bridge the gospel and culture in mission. While the method used by the author is to use reasech literature. The results of the study show that the contextualization method can be used in bridging the gospel and culture in missions and can even reduce the tension between the gospel and culture.

Keywords: Contextualization; Cultur; Gospel; Mission.

\section{Pendahuluan}

Acapkali perjumpaan injil dengan kebudayaan dapat menimbulkan ketegangan di tengah-tengah masyarakat pendengar injil. Beberapa contoh berikut mungkin dapat memperjelas pernyataan tersebut. Contoh pertama tampak dalam kisah pergulatan Kiai Sadrach dalam mewartakan injil di pulau Jawa. ${ }^{1}$ Guillot menyebutnya sebagai misionari pribumi dengan cara khas Jawa yang menggunakan bahasa dan tradisi-tradisi dalam menjembatani injil dengan budaya. ${ }^{2}$ Melalui pendekatannya itu, Sadrach telah mampu membawa banyak orang Jawa kepada Kristus. Bahkan pernah dicatat pengikutnya mencapai 7552 orang, jumlah ini melebihi para pengikut misionari yang tidak pernah mencapai angka 2000 meskipun telah bekerja selama lima puluh tahun. ${ }^{3}$ Namun dibalik keberhasilannya itu, tidak sedikit Sadrach menghadapi ketegangan dalam pewartaan injil dengan cara khas Jawa itu. Singgih menyebut salah satu ketegangan yang muncul adalah adanya tuduhan bahwa saat Sadrach menyandang predikat sebagai guru ngelmu, ia telah melakukan praktek sinkritisme dengan menggabungkan ajaran Kristen dengan Hidhu, Budha dan Islam. ${ }^{4}$ Selain itu, predikatnya sebagai guru ngelmu dan penambahan nama Suropranoto (diterjemahkan oleh lawan-lawannya sebagai "dewa yang memerintah) telah memunculkan tuduhan bahwa dia dianggap haus kedudukan

\footnotetext{
${ }^{1}$ C. Guillot, Kiai Sadrach: Riwayat Kristenisasi Di Jawa (Grafiti Pers., 1981).

${ }^{2}$ Ibid., 198.

${ }^{3}$ Sutarman Soediman Partonadi, Sadrach's Community and Its Contextual Roots: A Nineteenth Century Javanese Expression of Christianity (.: Rodopi, 1990), 94, 102, 129.

${ }^{4}$ Emmanuel Gerrit Singgih, Berteologi Dalam Konteks: Pemikiran-Pemikiran Mengenai Kontekstualisasi Teologi Di Indonesia. (Kanisius, 2000), 100.
} 
dan kehormatan serta telah mempraktekan ilmu sihir yang tidak cocok dengan injil. ${ }^{5}$ Contoh lain tampak dalam pelayanan Siswo pada tahun 1980 di Jawa Timur. Ketika dalam pelayanan misi dia berusaha menjembatani Injil dengan kebudayaan di daerahnya, lalu muncul kecaman dari berbagai pihak yang menuduhnya telah menghidupkan kembali tradisi-tradisi yang telah ditinggalkan oleh orang-orang Kristen di tempat dia melayani. ${ }^{6}$

Disamping beberapa contoh ketegangangan di atas, terdapat juga contohcontoh lain yang menunjukkan bahwa perjumpaan Injil dan kebudayaan dapat mendorong terciptanya pendekatan yang lebih arif. Sebagai contoh pendekatan para pekerja misi Kristen kepada suku Wana, di Sulawesi Tengah yang menggunakan konsep religi orang Wana tentang kematian. ${ }^{7}$ Rupanya melalui pendekatan tersebut, Injil dapat diterima bahkan mentransformasi kehidupan mereka. $^{8}$

Bercermin dari kasus-kasus di atas maka muncul sebuah pertanyaaan sebagai berikut bagimanakah seharusnya misionari menjembatani ketegangan antara injil dan budaya dalam bermisi agar pesan injil dapat diterima dengan baik dan tepat? Ada beberapa penelitian sebelumnya yang berusaha untuk mencari solusi dalam mengatasi masalah ketegangan injil dan budaya dalam misi. Nenohai dalam penelitiannya tentang pendekatan hermeneutik untuk penerjemahan Alkitab yang dilakukan Peter Middelkoop di Timor Barat, Provinsi Nusa Tenggara Timur mendapati bahwa penerjemahan Alkitab melalui bahasa Timor telah mampu mendekatkan Kristus dengan setiap individu di Timor, bahkan bahasa telah mempererat Kristus dan Kebudayaan, melebur bersama dalam satu-kesatuan. ${ }^{9}$ Rupanya melalui penelitian ini didapatkan gambaran bahwa ketegangan antara injil dan budaya dapat dijembatani melalui penggunaan bahasa suku sebagai media pewartaan injil. Selanjutnya, Sondegau di dalam penelitiannya tentang Kristologi dalam konteks kebudayaan suku

\footnotetext{
${ }^{5}$ Emanuel Gerrit Singgih, “A Postcolonial Biography of Sadrach: The Tragic Story of an Indigenous Missionary," Al-Jami'ah 53, no. 2 (2015): 379.

${ }^{6} \mathrm{~K}$ Siswanto, "Perjumpaan Injil Dan Tradisi Jawa Timuran Dalam Pelayanan Misi Kontekstual”," Evangelikal: Jurnal Teologi Injili dan Pembinaan Warga Jemaat 1, no. 1 (2017): 61.

${ }^{7}$ Ronaldy Dada and Alperiana Ermin Mosooli, "Konsep Agama Suku Wana Tentang Kematian, Implikasinya Bagi Misi Kristen Di Wana," Visio Dei: Jurnal Teologi Kristen 1, no. 2 (2019): 200-221.

${ }^{8}$ Ibid., 219.

${ }^{9}$ Jear Niklas Dominggus K. Nenohai, "Penenerjemahan Sebagai Media Pekabaran Injil Middelkop Ditinjau Dari Perspektif Hermenutika Hans Georg Gadamer," Gema Teologika 3, no. 2 (2018): 101-120.
} 
Migani di Papua menunjukkan bahwa penggunaan kisah tokoh mistis suku Migani yaitu Paegabega telah menolong gereja untuk dapat mewartakan Kristus dan ajaran-ajaran-Nya sehingga pewartaan ini sungguh-sungguh semakin mengakar dalam kultur masyarakat Migani. ${ }^{10}$ Di dalam penelitian ini, peneliti menemukan bahwa ada kearifan lokal dalam suku tertentu yang dapat dijadikan titik temu bagi pewartaan injil, bahkan mampu menjembatani pesan injil dengan masyarakat suku tersebut. Penelitian lain yang relevan dengan penelitian ini adalah yang dilakukan oleh Tari tentang teologi Tongkonan. Di dalam penelitiannya, peneliti menemukan bahwa perjumpaan antara Injil dan budaya Tongkonan di Toraja tidak menghilangkan identitas kekristenan, malahan budaya Tongkonan bisa dimaknai secara baru mengikuti norma-norma Injil Yesus Kristus. ${ }^{11}$ Melalui penelitian ini diperoleh hasil bahwa ketegangan antara Injil dan budaya di Toraja dapat dijembatai melalui dialog Injil dan Kebudayaan dalam menemukan nilai yang mampu mengubahkan manusia yang menganut kebudayaan tersebut. ${ }^{12}$

Persamaan penelitian ini dengan beberapa penelitian diatas adalah samasama berusahan meneliti tentang perjumpaan Injil dengan budaya dalam sebuah komunitas tertentu. Sedangkan perbedaannya adalah penelitian ini lebih berfokus pada uraian tentang metode kontekstualisasi dalam menjembatani Injil dan budaya. Adapun rumusan masalah dalam penelitian ini adalah bagaimanakah metode kontekstualisasi dapat menjembatani injil dan budaya dalam misi? Sedangkan penelitian ini bertujuan untuk menjelaskan bagaimana metode kontektualisasi dapat menjembatani Injil dengan budaya dalam misi.

\section{Metode Penelitian}

Penelitian ini menggunakan pendekatan studi kepustakaan (library reseach). Melalui pendekatan ini peneliti berusaha mengadakan penelusuran terhadap sumber-sumber kepustakaan dan memanfaatkannya untuk memperoleh data penelitian. ${ }^{13}$ Sumber-sumber kepustakaan tersebut meliputi dokumen, buku, majalah, kisah-kisah sejarah, dsb. ${ }^{14}$ Menurut Sarwono, pendekatan library

${ }^{10}$ Kleopas Sondegau, "Kristologi Dalam Konteks Kebudayaan Suku Migani Di Papua" 17, no. 1 (2017): 60-79.

${ }^{11}$ Ezra Tari, "Teologi Tongkonan: Berteologi Dalam Konteks Budaya Toraja” 2, no. 2 (2018): 101

${ }^{12}$ Ibid., 93.

${ }^{13}$ Mestika. Zed, Metode Peneletian Kepustakaan (Yayasan Obor Indonesia, 2004), 1.

${ }^{14}$ Mardalis, Metode Penelitian Suatu Pendekatan Proposal (Jakarta: Bumi Aksara, 1999). 
reseach juga dapat menggunakan hasil-hasil penelitian sebelumnya yang berguna untuk mendapatkan landasan teori dari masalah yang sedang diteliti. ${ }^{15}$ Adapun prosedur penelitian kepustakaan ini adalah sebagai berikut; ${ }^{16}$ (1) peneliti mengadakan pemilihan topik, (2) mengeksplorasi informasi, (3) menentukan fokus penelitian, (4), pengumpulan sumber data, (5) persiapan penyajian data, (6) penyusunan laporan. Sedangkan analisa data pada penelitian ini menggunakan Content Analysis dimana analisis ini digunakan untuk mendapatkan simpulan yang sahih sehingga dapat diteliti ulang berdasarkan konteksnya. $^{17}$

\section{Pembahasan dan Hasil}

Pada hakikatnya Injil merupakan Kabar Baik bagi setiap manusia, dimana jika itu diberitakan akan memberikan upah bagi sang pemberitanya dan juga memunculkan reaksi serta tindakan bagi pendengarnya, yaitu ucapan terima kasih sebagai wujud kurban kepada Allah. ${ }^{18}$ Pengertian tersebut didasarkan atas

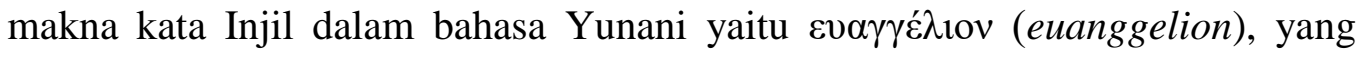
secara umum berarti kabar baik atau berita baik. ${ }^{19}$ Kata ini terdiri dari dua kata Yunani yaitu eu dan anggelia dimana kata eu memiliki pengertian baik, sedangkan kata anggelia berarti suatu berita. ${ }^{20}$

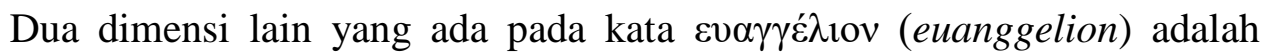
upah bagi sang pemberita dan reaksi sang pendengar. Rupanya dalam kebiasaan masyarakat Yunani, sang pembawa berita baik akan selalu mendapatkan upah. ${ }^{21}$ Sedangkan bagi para pendengarnya hal itu akan memunculkan reaksi serta tindakan, yaitu membawa kurban sebagai ucapan syukur dan terima kasih. ${ }^{22}$

Selanjutnya, inti pesan Injil yang harus diberitakan kepada seluruh umat manusia adalah bahwa Kristus telah menderita, mati untuk menanggung dosadosa setiap manusia dan dikuburkan lalu bangkit pada hari yang ketiga sesuai

${ }^{15}$ Jonathan Sarwono, Metode Penelitian Kuantitatif Dan Kualitatif (Yogyakarta: Graha Ilmu, 2006).

${ }^{16}$ C. C. Kuhltau, Teaching The Library Research (USA: Scarecrow Press Inc, 2020).

${ }^{17}$ Klaus Krippendorff, Analisis Isi Pengantar Teori Dan Metodologi (Jakarta: PT. Raja Grafindo Persada, 1993).

${ }^{18}$ David Eko Setiawan, "Dampak Injil Bagi Transformasi Spiritual Dan Sosial," BIA': Jurnal Teologi dan Pendidikan Kristen Kontekstual 2, no. 1 (2019): 85.

${ }^{19}$ Marulak Pasaribu, Eksposisi Injil Sinoptik (Malang: Gandum Mas, 2005), 13.

${ }^{20}$ Ibid.

${ }^{21}$ Ibid., 14.

${ }^{22}$ Ibid. 
dengan Kitab Suci. ${ }^{23}$ Semua peristiwa tersebut merupakan wujud solidaritas Allah kepada manusia ${ }^{24}$ dan juga sebuah fakta sejarah yang tak terbantahkan. ${ }^{25}$ Sehingga secara ringkas dapat dikatakan bahwa memberitakan Injil adalah mewartakan kabar baik dari Allah yang telah mengutus Anak-Nya yaitu Yesus Kristus untuk menjadi Tuhan dan Juru Selamat bagi setiap umat manusia yang berdosa. ${ }^{26}$

Inti pesan injil di atas telah mendorong Rasul Paulus untuk menjangkau setiap orang bagi Kristus. Bagi Paulus, Injil adalah kekuatan Allah yang mampu menyelamatkan setiap orang yang percaya, pertama-tama orang Yahudi, tetapi juga orang Yunani (Roma 1:16). Berdasarkan pemahaman Paulus akan Injil tersebut, Gea berpendapat bahwa di dalam injil ada kekuatan Illahi yang mengubahkan dan memperdamaikan setiap manusia dengan Allah, selain itu juga melalui Injil, keselamatan tidak dibatasi, namun untuk semua orang, ${ }^{27}$ baik yang hidupnya mapan maupun yang termarginalkan. ${ }^{28}$

Pesan Injil yang satu itu diberitakan kepada semua orang dengan berbagai metode agar mereka dapat dijangkau sesuai dengan konteks kehidupannya. Hal ini tampak dalam pewartaan Injil yang dilakukan oleh Rasul Paulus. Sebagai rasul, pewarta dan teolog, ia tidak segan untuk memanfaatkan banyak sarana dan unsur dari kebudayaan masyarakat yang menjadi alamatnya. ${ }^{29}$ Dalam suratnya kepada jemaat di Korintus, dia menjelaskan bagaimana pewarataan itu dilakukan kepada segenap lapisan masyarakat dengan berbagai latar belakang budaya (1Kor. 9: 19-23). Dia berusaha menyesuaikan diri dengan konteks budaya masyarakat yang dilayaninya dengan tujuan agar dia dapat memenangkan sebanyak mungkin orang bagi Kristus. ${ }^{30}$ Sebagai contoh, ketika Paulus bersama dengan orang Yahudi, ia tunduk terhadap hukum Taurat supaya hal tersebut dapat menghilangkan prasangka para pendengar Injil itu sehingga kemudian dia mendapat kesempatan untuk membujuk mereka agar mendengar

${ }^{23}$ Kalis Stevanus, Panggilan Teragung (Yogyakarta: Penerbit Andi, 2019), 38.

${ }^{24}$ Sonny Zaluchu, "Penderitaan Kristus Sebagai Wujud Solidaritas Allah Kepada

Manusia," DUNAMIS: Jurnal Penelitian Teologi dan Pendidikan Kristiani 2, no. 1 (2017): 71.

${ }^{25}$ Stevanus, Panggilan Teragung, 38.

${ }^{26}$ Ibelala Gea, "Beritakan Injil Kepada Segala Makhluk," BIA': Jurnal Teologi dan Pendidikan Kristen Kontekstual 1, no. 1 (2018): 56-69.

${ }^{27}$ Ibid., 58-59.

${ }^{28}$ Fransiskus Irwan Widjaja, "Papua Dan Panggilan Macedonia Di Zaman Millennium Baru," DIEGESIS: Jurnal Teologi Kharismatika 2, no. 1 (2019): 35-38.

${ }^{29}$ Martin Harun, "Perjumpaan Injil Dan Kebudayaan Dalam Kerasulan Paulus," Studia Philosophica et Theologica 16, no. 1 (2016): 9.

${ }^{30}$ Howard A. Hatton Loh, I. Jin, Pedoman Penafsiran Alkitab: Surat Paulus Yang

Pertama Kepada Jemaat Di Korintus (Jakarta: Lembaga Alkitab Indonesia, 2019), 242-243. 
dan percaya akan Injil. ${ }^{31}$ Hal yang sama juga dilakukan oleh Paulus kepada lapisan masyarakat yang lain. ${ }^{32}$ Namun demikian, keragaman konteks masyarakat yang dihadapi Paulus, tidak membuatnya kemudian mengubah kemurnian berita Injil. ${ }^{33}$ Dalam pewartaannya, Paulus selalu menjaga kemurnian berita Injil.

\section{Kebudayaan, Kepribadian dan Masyarakat}

Sebagai bagian dari masyarakat, manusia pada dasarnya tidak dapat dilepaskan dari budaya, karena dia sendiri pada hakikatnya adalah Homo Humanus, yang artinya mahkluk budaya. ${ }^{34}$ Sedangkan dalam lingkup yang lebih luas, masyarakat dan kebudayaan adalah dua hal yang tidak dapat dipisahkan. Soekanto mengatakan bahwa tak ada masyarakat yang tidak mempunyai kebudayaan dan sebaliknya tak ada kebudayaan tanpa masyarakat sebagai wadah dan pendukungnya. ${ }^{35}$ Keterkaitan tersebut menarik untuk dipelajari, mengingat dengan mampelajari kebudayaan suatu kelompok masyarakat maka akan diperoleh juga pemahaman tentang kepribadian dari anggota masyarakat tersebut.

\section{Pengertian Kebudayaan}

Kata kebudayaan berasal dari budhaya yang dalam bahasa sansekerta berarti akal, sehingga kebudayaan dapat diartikan sebagai hasil pemikiran atau akal manusia. ${ }^{36}$ Verkuyl mendefinisikan kebudayaan sebagai: "segala sesuatu yang diciptakan oleh akal manusia, yang berhubungan erat dengan pengerjaan (pengusahaan, pengelolaan) kemungkinan-kemungkinan dalam alam penciptaan oleh manusia dalam lingkup kehidupan." ${ }^{37}$ Berdasarkan penjelasan tersebut maka kebudayaan dapat diartikan sebagai segala sesuatu yang berkaitan dengan kebiasaan dan cara hidup manusia secara utuh, yang meliputi tentang bagaimana ia berpikir, dan mengisi kehidupannya dengan melakukan apa yang

${ }^{31}$ Matthew. Henry, Tafsiran Surat Roma, 1 \& 2 Korintus (Surabaya: Penerbit Momentum, 2015), 649.

${ }^{32}$ Ibid., 649-650.

${ }^{33}$ David Eko Setiawan, Misi Perintisan Jemaat Alkitabiah-Kontekstual (Yogyakarta: CV. Diandra Kreatif, 1997), 25.

${ }^{34}$ Sarinah, Ilmu Budaya Dasar (Sleman: CV Budi Utama, 2019), 6.

${ }^{35}$ Soerjono. Soekanto, Sosiologi Suatu Pengantar (Jakarta: Rajawali Pers, 2009), 187.

${ }^{36}$ Sarinah, Ilmu Budaya Dasar, 11.

${ }^{37}$ J Verkuyl, Etika Kristen Dan Kebudayaan, 2nd ed. (Jakarta: Badan Penerbit Kristen, 1966), 13-14. 
dipikirkannya, dengan tujuan untuk menata, memelihara serta mempertahankan kehidupannya di dalam konteks dimana dia berada. ${ }^{38}$

Selanjutnya, Sarinah mengartikan kebudayaan sebagai cara hidup yang berkembang dan dimiliki bersama oleh sebuah kelompok orang dan diwariskan dari generasi ke generasi. ${ }^{39}$ Lalu bagiamanakah wujud kebudayaan itu? J.J. Hoenigman dalam Koentjaraningrat membedakan wujud kebudayaan menjadi tiga yaitu gagasan, aktivitas, dan artefak. ${ }^{40}$ Gagasan merupakan wujud kebuayaan yang bersifat abstrak dan berada di dalam pikiran manusia, semisal ide-ide, nilai-nilai, norma-norma peraturan dan sebagainya. ${ }^{41}$ Sedangkan aktivitas adalah wujud kebudayaan yang tampak dalam tindakan manusia dalam berinteraksi, serta bergaul dengan manusia lainnya berdasarkan pola-pola tertentu yang didasarkan atas adat kebiasaan mereka. ${ }^{42}$ Artefak adalah wujud kebudayaan secara fisik yang dapat berupa benda-benda dan semua karya manusia yang dapat dilihat, diraba dan didokumentasikan. ${ }^{43}$

\section{Kepribdian dan Masyarakat}

Kepribadian dapat didefinisikan sebagai organisasi faktor-faktor biologis, psikologis dan sosiologis yang mendasari prilaku individu. ${ }^{44}$ Kepribadian setiap individu mencakup kebiasaan-kebiasaan, sikap dan sifat-sifat yang khas yang berkembang ketika dia berhubungan dengan individu yang lain. Afiah mengutip Castillo, berpendapat bahwa kepribadian merupakan hasil interaksi antara faktor bawaan dan lingkungan. ${ }^{45}$ Di tengah-tengah masyarakat, setiap individu akan mengalami socialization, yaitu proses mempelajari norma-norma dan kebudayaan masyarakat dimana dia menjadi anggotanya. ${ }^{46}$ Dalam proses ini kepribadian individu tersebut mendapatkan pembentukan sikap untuk berprilaku sesuai dengan prilaku kelompoknya.

${ }^{38}$ Yakoub Tomatala, Antropologi: Dasar Pendekatan Pelayanan Lintas Budaya (Jakarta: YT Leadership Foundation, 2007), 17.

${ }^{39}$ Sarinah, Ilmu Budaya Dasar, 11.

${ }^{40}$ Koentjaraningrat, Pengantar Ilmu Antropologi, . (Jakarta: Rineke Cipta, 2000), 186.

${ }^{41}$ Ibid.

42 Ibid.

${ }^{43}$ Ibid.

44 Alexander Kuman Roucek, Joseph Slabey, Roland L. Warren, Sociology: An Introduction (Littlefield, Adams \& Company, 1968), 23.

${ }^{45}$ Nur Afiah, "Kepribadian Dan Agresivitas Dalam Berbagai Budaya," Buletin Psikologi 23, no. 1 (2015): 16.

${ }^{46}$ Soekanto, Sosiologi Suatu Pengantar, 204. 
Berdasarkan penjelasan di atas, masyarakat sebagai kumpulan individu dalam suatu wilayah, dapat menjadi salah satu penentu bagi pembentukan kepribadian individu. Masyarakat memiliki pola prilaku yang umum yang dapat memengaruhi dan membatasi prilaku individunya. Melaluinya, kepribadian individu dapat dibentuk dan berkembang. Soekanto memberikan contoh sebagai berikut: "bagi masyarakat Indonesia dan sebagian besar masyarakat dunia lainnya meludah merupakan perbuatan yang tidak sopan, namun bagi orangorang Masai di Afrika menganggap perbuatan tadi sebagai ucapan terima kasih atau tanda suka pada seseorang." 47 Disini tampak bahwa budaya sebuah masyarakat memberikan pengaruh terhadap kepribadian individunya. Sehingga dapat dikatakan bahwa dengan mempelajari budaya masyarakat tertentu, akan didapati kesempatan juga untuk mengenal prilaku serta kepribadian dari individu-individu di dalam masyarakat tersebut.

\section{Relasi antara Kepribadian, Masyarakat dan Kebudayaan}

Pada dasarnya masyarakat dan kebudayaan merupakan perwujudan dari kepribadian manusia yang tercermin dari prilakunya. ${ }^{48}$ Sutherland menjelaskan bahwa ketiga aspek yaitu kebudayaan, kepribadian dan masyarakat mempunyai hubungan yang saling memengaruhi satu dengan yang lainnya. ${ }^{49}$

Masyarakat adalah orang yang hidup bersama yang menghasilkan kebudayaan. ${ }^{50}$ Selanjutnya, kebudayaan di dalam suatu masyarakat turut memberikan suatu sumbangan pada pembentukan kepribadian seseorang. ${ }^{51}$ Mengapa demikian? Karena kepribadian suatu individu dalam suatu masyarakat walaupun berbeda-beda satu sama lain, dirangsang dan dipengaruhi oleh nilai dan norma dalam dalam suatu sistem budaya dan juga oleh sistem sosial yang telah diinternalisasi melalui proses sosialisasi dan proses pembudayaan selama hidup, sejak kecilnya. ${ }^{52}$ Demikianlah ketiganya saling memengaruhi satu dengan yang lainnya.

${ }^{47}$ Ibid., 205.

${ }^{48}$ Ibid., 202.

${ }^{49}$ Robert L Sutherland, Introductory Sociology, 6th ed. (Chicago: J.B. Lippincott Company, 1961), 59.

${ }^{50}$ Soekanto, Sosiologi Suatu Pengantar, 187.

${ }^{51}$ Bagja. Waluya, Sosiologi: Menyelami Fenomena Sosial Di Masyarakat (PT Grafindo Media Pratama, 2007), 80.

52 Ibid. 


\section{Mengkomunikasikan Injil Melalui Kebudayaan}

Perjumpaan Injil dengan kebudayaan di ladang misi, adakalanya munculkan ketegangan. Bahkan tidak sedikit misonari yang mengabaikan hal itu, dan tetap mewartakan Injil. Kekeliruan para pewarta Injil adalah mengabaikan begitu saja budaya, sehingga seolah-olah Injil merupakan barang baru yang tidak ada sangkutpautnya dengan budaya. ${ }^{53}$ Pengabaian tersebut merupakan salah satu penyebab ketidakefektifan dalam misi. ${ }^{54}$ Maka dari itu pewarta Injil perlu menggumuli kebudayaan masyarakat yang dilayaninya, agar pesan Injil dapat disampaikan berdasarkan konteks kebudayaan mereka.

Contoh menarik dari kasus ini adalah kisah pelayanan misi Don dan Carol Richardson dalam mencari cara untuk mengkomunikasikan Injil kepada orangorang suku Sawi di Irian Barat. Hasselgrave mengisahkan pergumulan kedua misionari tersebut di tengah-tengah suku dengan latar belakang kebudayaan yang unik. ${ }^{55}$ Bagi suku Sawi, kebajikan yang tertinggi dalam konteks budaya mereka adalah pengkhianatan. Sehingga ketika Don mengisahkan pengkhianatan Yudas terhadap Yesus, menurut perspektif kebudayaan suku Sawi, Yudaslah yang menjadi pahlawan sedangkan Yesus adalah pecundang. Hal ini memunculkan kesukaran bagi orang Sawi dalam memahami berita keselamatan. Selanjutnya kedua misionaris itu menggumuli budaya masyarakat suku Sawi dan akhirnya mereka menemukan poin of contac dalam menjelaskan pesan Injil berdasarkan persepsi budaya mereka sehingga akhirnya suku Sawi menerima Tuhan Yesus.

Isi Injil yaitu Yesus Kristus dan karya-Nya bagi umat manusia, pada dasarnya tetap sama dan tidak berubah, namun memahami, mengkomunikasikan dan membuat-Nya relevan pada satu konteks ke konteks yang lain tak pernah selesai dan terus berubah seturut pengalaman dan kebudayaan manusia yang terikat ruang dan waktu tertentu. ${ }^{56}$ Para pewarta Injil/misionari perlu menyadari bahwa pada hakikatnya Injil tidak terpisah dengan kebudayaan. Jika pewarta Injil hanya memiliki pengetahuan Alkitab tanpa pengetahuan tentang masyarakat di sekitarnya, maka mereka akan memproklamasikan suatu berita yang tidak relevan dan sama sekali tanpa arti, namun sebaliknya, jika pewarta Injil hanya memiliki pengertian budaya di sekitarnya tanpa pengertian yang

\footnotetext{
${ }^{53}$ Gea, "Beritakan Injil Kepada Segala Makhluk," 57.

${ }^{54}$ Firman Panjaitan and Hendro Siburian, "Misi Kristologi Dalam Konteks Kebudayaan," Logia 1, no. 1 (2020): 42.

${ }^{55}$ D. J Hesselgrave, Communicating Christ Cross-Culturally : Mengomunikasikan Kristus Secara Lintas Budaya (Malang: Malang Literatur SAAT, 2004), 230.

${ }^{56}$ Sondegau, "Kristologi Dalam Konteks Kebudayaan Suku Migani Di Papua," 61.
} 
benar tentang Injil dan dosa, maka mereka tidak memiliki berita untuk disampaikan sehingga jelas bahwa pengertian akan keduanya itu sangat penting bagi pewarta Injil. ${ }^{57}$ Injil hadir di tengah-tengan masyarakat dengan segala latar belakang budayanya. Melalui kebudayaan mereka, Injil dapat dikomunikasikan dan direfleksikan, sehingga hal tersebut akan mempermudah penerima pesan Injil tersebut.

\section{Prinsip dan Langkah Mengkomunikasikan Injil Melalui Kebudayaan}

Bagaimanakah seharusnya pewarta mengkomunikasikan pesan Injil melalui kebudayaan itu? Sebelum menjawab pertanyaan tersebut maka perlu disajikan beberapa prinsip dasar berkomunikasi. Hal ini penting, mengingat prinsip-prinsip ini dapat berguna bagi terciptanya komunikasi yang efektif. Tomatala memberikan sembilan prinsip dasar dalam berkomunikasi lintas budaya: ${ }^{58}$ Pertama, pada dasarnya komunikasi memiliki tujuan yaitu agar pendengar memahami berita yang disampaikan dan mendorongnya untuk bertindak sesuai berita itu. Kedua, pemahaman pendengar sangat tergantung dengan penyampaian berita. Ketiga, komunikator menyampaikan berita melalui lambang budaya yang memberi rangsangan kepada pikiran pendengar sesuai dengan pengertiannya atas lambang tersebut. Dalam hal ini yang dipindahkan adalah beritanya bukan pengertiannya. Keempat, komunikasi berita akan lebih efektif jika komunikator berorientasi kepada pendengar. Kelima, bentuk komunikasi harus sesuai dengan pengertian pendengar agar pesan yang disampaikan dapat memberikan impact yang memadai. Keenam, pengaruh komunikasi yang luar biasa akan terjadi dalam interaksi antar pribadi. Ketujuh, komunikasi akan sangat efektif bila prosesnya terjadi di dalam konteks yang sama. Kedelapan, komunikasi akan lebih efektif bila komunikator memiliki pengaruh dan kredibilitas dalam lingkup kebudayaan tertentu. Kesembilan, komunikasi akan lebih efektif bila berita yang disampaikan berhubungan dengan kehidupan dimana pendengar berada. Kesepuluh, komunikasi akan lebih efektif bila pendengar mampu berpartisipasi dengan berita tersebut.

Berdasarkan penjelasan di atas dapat disimpulkan bahwa untuk mengkomunikasikan Injil secara efektif pada masyarakat dengan latar belakang kebudayaan tertentu, faktor-faktor kebudayaan perlu diperhitungkan agar tercipta keseimbangan serta perubahan yang positif dan efektif. Selanjutnya

\footnotetext{
${ }^{57}$ Rahmiati Tanudjaja, "Kontekstualisasi Sebagai Sebuah Strategi Dalam Menjalankan Misi : Sebuah Ulasan Literatur," Veritas : Jurnal Teologi dan Pelayanan 1, no. 1 (2000): 25.

${ }^{58}$ Y.Y Tomatala, Penginjilan Masa Kini (Penerbit Gandum Mas, 1997), 59-60.
} 
bagiamanakah langkah-langkah dalam mengkomunikasikan Injil melalui kebudayaan itu?

Pertama, komunikator wajib menguasai isi berita yang disampaikan. Penguasaan ini penting agar dia benar-benar memahami arti/makna yang sesungguhnya dari berita yang akan disampaikannya itu. Berkaitan dengan Injil, maka komunikator perlu menguasai hakikat Injil dan maknanya. Jika itu masih bias maka sangat dimungkinkan para pendengar akan bias pula dalam memahaminya. Kedua, komunikator perlu mempertimbangkan bentuk-bentuk komunikasi dalam kebuadayaan yang mungkin akan menjadi medium Injil. Tomatala memberikan beberapa contoh bentuk-bentuk komunikasi dalam kebudayaan antara lain; ${ }^{59}$ Cerita rakyat. Cerita rakyat pada dasarnya merupakan alat pendidikan yang dipakai dalam kebudayaan, sehingga setiap generasi dapat meneruskan nilai-nilai luhur budaya kepada generasi berikutnya. Bentuk komunikasi budaya selanjutnya adalah seni rakyat. Seni rakyat dapat berupa musik, drama dan tarian. Melalui seni rakyat ini biasanya masyarakat mentransmisikan nilai-nilai moral serta cita-cita luhur mereka. Seni lukis, ukir atau pahatan merupakan bentuk komunikasi kebudayaan cenderung non verbal. Bentuk komunikasi budaya tersebut berfungsi mentransmisikan arti dari filsafat hidup yang dianut oleh peserta budaya dari suatu kebudayaan. Ketiga, komunikator seyogyanya menemukan point of contac antara berita dengan bentuk-bentuk kebudayaan yang ada. Disini diperlukan kematangan untuk melakukan proses hermeneutik terhadap berita dan bentuk budaya yang ada. Pada tataran ini komunikator beranjak dari teks sebagai sumber yang memberi signifikansi kepadanya, kemudian dia memberi arti/makna pada teks. ${ }^{60}$ Setelah proses ini selesai maka komunikator memberikan signifikansi kepada budaya penerima (pendengar) melalui betuk-bentuk budaya yang ada, yang kemudian memberi arti kepada komunikator (pemberita). ${ }^{61}$ Diharapkan melalui proses ini ditemukan point of contac untuk mengkomunikasikan Injil melalui kebudayaan. Keempat, komunikator mengkonstruksi pesan Injil yang dibalut dengan kebudayaan lalu membagikannya kepada peserta budaya berdasarkan poin of contact tersebut. Berita Injil dapat dibungkus dalam bentuk yang baru sehingga dapat diterima oleh penerima pesan tersebut dalam budaya mereka. ${ }^{62}$

${ }^{59}$ Tomatala, Antropologi: Dasar Pendekatan Pelayanan Lintas Budaya, 22-223.

${ }^{60}$ Ferry Y. Mamahit, "Hermeneutika Peleburan Dua Horizon Anthony Thiselton Dan Tantangan Dari Antropologi Lintas Budaya," Veritas : Jurnal Teologi dan Pelayanan 18, no. 1 (2019): 39-40.

\footnotetext{
${ }^{61}$ Ibid.

${ }^{62}$ Ibid., 40.
} 


\section{Kontekstualisasi: Sebuah Metode yang Menjembatani Injil dan Kebudayaan}

Perjumpaan Injil dan Kebudayaan acapkali menimbulkan ketegangan sehingga perlu dicarikan metode yang sesuai untuk menjembataninya. Kesemuanya itu bertujuan agar pesan Injil yang ditrasmisikan melalui kebudayaan dapat diterima dengan baik dan benar. Sehubungan dengan hal tersebut, terdapat istilah dalam dunia misi dan teologi yang mendorong kepekaan terhadap kebudayaan. Istilah tersebut adalah kontekstualisasi. Istilah ini diperkenalkan oleh Theological Education Fund (TEF) pada tahun 1972 dalam kaitanya dengan peningkatan kualitas pendidikan teologia di Negara Dunia Ketiga dengan mendorong suatu pemikiran kembali tentang berteologia yang peka terhadap kebudayaan dan komunikasi. ${ }^{63}$ Namun demikian menurut Tanudjaja, para misiolog sebenarnya telah mengenal ide ini jauh sebelum TEF bersidang, yaitu terdapat di dalam Kitab Suci. ${ }^{64}$

\section{Pengertian Kontekstualisasi}

Kontekstualisasi telah didefinisikan oleh para sarjana sebagai berikut; Kato mengartikannya sebagai "pembuatan konsep atau ideal-ideal relevan dalam situasi tertentu berarti." ${ }^{\prime 65}$ Nichollas mendefinisikan sebagai "terjemahan dari isi kerajaan Allah yang tidak berubah ke dalam bentuk verbal yang berarti bagi orang-orang di dalam kebudayaan mereka yang terpisah dan di dalam situasi eksistensial khusus mereka". ${ }^{66}$ Peters menyebut kontekstualisasi sebagai "implikasi-implikasi logis dari Injil dalam situasi tertentu." ${ }^{67}$ Sedangkan Conn mengatakannya sebagai "proses keberhatian seluruh umat Allah pada klaimklaim hermeneutikal Injil.,"68

Dalam kaitannya dengan misi, Tomatala mengartikan kontekstualisasi sebagai "usaha untuk memahami dan menganggap penting konteks khusus dari masing-masing masyarakat dan pribadi dalam istilah-istilahnya sendiri dan dalam semua dimensi budaya, keagamaan, sosial, politik ekonomi serta

${ }^{63}$ Hesselgrave, Communicating Christ Cross-Culturally: Mengomunikasikan Kristus Secara Lintas Budaya, 129.

64 Tanudjaja, "Kontekstualisasi Sebagai Sebuah Strategi Dalam Menjalankan Misi: Sebuah Ulasan Literatur," 19.

${ }^{65}$ H. Byang Kato, The Gospel, Cultural Context, and Religious Syncritism (Minneapolis: World Wide Publications, 1975), 1217.

${ }^{66}$ Bruce. J Nicholls, Theological Education and Evangelization, n.d., 647.

${ }^{67}$ George W. " Peters, Issues Confronting Evangelical Missions." Evangelical Missions Tomorrow (Pasadena: William Carey, 1977), 169.

${ }^{68}$ H. M. Conn, "Contextualization: A New Dimension for Cross-Cultural Hermeneutic," Evangelical Missions Quarterly 14, no. 1 (1978): 42. 
mempertajam apa yang Injil katakan kepada orang-orang di dalam konteks tersebut." ${ }^{69}$ Melalui usaha tersebut akan terbuka peluang bagi penyampaian Injil secara tepat untuk setiap konteks. ${ }^{70}$ Sedangkan Hesselgrave mendefinisikannya sebagai berikut: "usaha untuk mengkomunikasikan pesan manusia, karya-karya, perkataan, dan kehendak Allah dalam cara yang setia kepada penyataan Allah, khususnya pada waktu hal ini dikeluarkan di dalam ajaran-ajaran Kitab Suci, dan yang penuh arti bagi responden-responden di dalam konteks kultural dan eksistensial mereka masing-masing." 71 Singkatnya, Kontekstualisasi merupakan upaya untuk menemukan metode terbaik mengkomunikasikani pesan Injil sehingga menjadi relevan bagi budaya yang menjadi penerima pesan tersebut.

\section{Teologi Kontekstualisasi}

Tomatala mengatakan bahwa prinsip kerja konsep kontekstualisasi berhubungan erat dengan sifat teologi situasional. ${ }^{72}$ Artinya bahwa kontekstualisasi berhubungan erat dengan refleksi teologi yang mengaitkan teks (Alkitab) dengan konteks (situasi kehidupan). Hubungan ini menghasilkan suatu intreksi dinamis yang kemudian memunculkan "suatu teologi kontekstualisasi." 73 Adapaun sifat teologi konktekstualisasi yang berhubungan dengan refleksi teologi memiliki fungsi sebagai berikut: ${ }^{74}$ Pertama, refleksi teologi bersifat kritis dan propetikal. Artinya bahwa refleksi teologis harus memahami teks dalam situasi aslinya dan menerapkannya dalam situasi saat ini, dimana dalam terang Firma itu, orang percaya pada setiap tempat menganalisa, menafsirkan dan menghakimi sejarah.

Kedua, refleksi teologi secara kondisional dibungkus oleh kenyataan sejarah dan budaya dari setiap konteks sejarah. Disini setiap orang percaya ditantang untuk selalu memperhatikan cara berpikir, konsep serta lambang di dalam suatu masyarakat agar dapat dijadikan alat bagi ekspresi iman.

Ketiga, refleksi teologi kontekstualisasi berdasarkan sikap self determination, yaitu sikap menetapkan sendiri pandangan teologi tanpa dipengaruhi oleh refleksi atau budaya asing. Kebenaran Firman Allah harus diterjemahkan dalam situasi budaya secara keseluruhan sehinga Firman itu dapat

${ }^{69}$ Tomatala, Penginjilan Masa Kini, 64.

${ }^{70}$ Ibid.

${ }^{71}$ Hesselgrave, Communicating Christ Cross-Culturally : Mengomunikasikan Kristus Secara Lintas Budaya, 138.

${ }^{72}$ Tomatala, Penginjilan Masa Kini, 66.

${ }^{73}$ Ibid.

${ }^{74}$ Ibid., 66-67. 
diterima dan dipastikan menjadi miliki budaya tersebut. Ajaran Alkitab harus diterapkan dalam struktur pikiran dan kehidupan budaya, sehingga Kristus menjadi Tuhan atas dan dalam setiap budaya tersebut.

\section{Proses Kontekstualisasi}

Ada beberapa faktor yang harus dipertimbangan dalam proses kontekstualisasi. Beberapa faktor tersebut dijelaskan oleh Tomatala berikut: ${ }^{75}$ Pertama, Alkitab memandang kebudayaan secara positif dan negatif. Alkitab menjelaskan adanya Mandat Budaya (Kej. 1:28) dimana mandat tersebut masih tetap berlaku pasca kejatuhan. Namun demikian Alkitab juga mencatat bahwa pengerjaan mandat itu dilaksanakan di dalam keberdosaan (Roma 3:23; 5:12 dst.) yang dapat membawa ketidakstabilan dan keseimbangan hidup. Kedua, di dalam setiap kebudayaan manusia terdapat unsur keburukan, kebangkrutan moral, dan kesia-saiaan dalam kebudayaan manusia. Hal ini merupakan akibat langsung dan tidak langsung dari dosa. Ketiga, Adanya fakta bahwa inkarnasi Yesus Kristus terjadi dan mengekspresikan diri dalam dan melalui kebudayaan. Kenyataan ini didukung fakta bahwa isi Alkitab pun diekspresikan melalui kebudayaan manusia.

\section{Model dan Pola Kontekstualisasi}

Sebagai suatu usaha untuk menjembatani ketegangan antara Injil dan budaya, Kontekstualisasi memiliki beberapa model dan pola. Pada bagian ini akan dipaparkan lima model dan pola kontektulasasi berdasarkan penjelasan Tomatala): ${ }^{76}$ Pertama, Model Akomodasi (Kis. 17:28). Model ini mengedepankan sikap menghargai dan keterbukaan terhadap kebudayaan asli yang dilakukan dalam sikap, kelakuan, dan pendekatan praktis dalam tugas misionari. Obyek akomodasi adalah kehidupan budaya yang menyeluruh dari suatu bangsa, baik dari segi fisik, sosial maupun ideal. Model ini mendorong poses penetrasi dan penerapan Injil yang mengambil alih unsur budaya setempat untuk mengekspresikan dan meningkatkan sambutan atas Injil. Pada model ini terjadi proses perpaduan nilai hidup Kristiani dimana Kristus menjadi penyempurna dan pelengkap aspirasi budaya. Dengan demikian akan terdapat sikap positif terhadap Injil yang didasarkan atas pandangan bahwa anugerah Allah (Injil) tidak menghancurkan budaya manusia, tetapi justru mlengkapi dan menyempurnakan. Kedua, Model Adaptasi. Model ini berusaha untuk

\footnotetext{
${ }^{75}$ Ibid., 67.

${ }^{76}$ Ibid., 67-69.
} 
menggunakan bentuk dan ide budaya yang dikenal oleh masyarakat yang disapa oleh Injil. Pada model ini proses asimilasi unsur budaya untuk mengekspresikan Injil tidak dilakukan. Tujuan adaptasi adalah mengekspresikan dan menerjemahkan Injil dalam istilah setempat sehingga menjadi relevan dalam situasi budaya tertentu.

Ketiga, Model Prossesio. Pada Model Prossesio terdapat sikap negatif terhadap kebudayaan. Hal ini didsarkan pada keyakinan bahwa kebudayaan pada dasarnya telah rusak oleh karena dosa, sehingga diyakini tidak ada kebaikan yang muncul dari sana. Model ini melakukan proses seleksi, penolakan, reinterpretasi dan rededikasi terhadap kebudayaan. Keempat, Model atau Pola Transformasi. Di dalam model atau pola ini terdapat keyakinan bahwa Allah itu supra budaya. Allah itu di atas budaya; dan melalui budaya itu pula, Allah berinteraksi dengan manusia. Bila seseorang diperbaharui Allah, maka inti kebudayaannya juga dibaharui (II Korintus 5:17). Kelima, Model Dialektik. Di dalam Model Dialektik terjadi proses interaksi antara teks dengan konteks. Konsep ini didukung oleh perkiraan yang kuat bahwa perubahan pasti dalam setiap kebudayaan. Untuk setiap kurun waktu, perubahan itu terjadi secara dinamis. Dengan demikian Gereja harus menggunakan peran kenabiannya untuk menganalisa, menginterpretasi dan menilai setiap keadaan.

\section{Fungsi Kontektualisasi}

Kontekstualisasi sebagai metode dalam menjembatani Injil dan kebudayaan, memiliki beberapa fungsi. Whiteman menunjukkan tiga fungsi dari kontekstualisasi yaitu; ${ }^{77}$ Pertama, fungsi konstruktif. Fungsi ini menekankan pendirian gereja lokal melalui pemberitaan injil kepada komunitas yang berlatar belakang kebudayaan tertentu. Bahkan melalui usaha kontekstualisasi itu diharapkan pesan dan kesaksian gereja dapat diterima dalam kebudayaan lokal, dan akhirnya terwujud pemuridan yang berakar pada konteks budaya lokal.

Kedua, fungsi transformatif. Menurut Whiteman, Kontekstualisasi akan memper-jumpakan Injil dengan kebudayaan dalam suasana konfrontatif, karena memang begitulah sifat Injil. Injil akan mengancam setiap nila-nilai di dalam kebudayaan yang bertentangan dengan nila-nilai Kerajaan Allah. Injil akan terang-terangan menyingkapkan kedok-kedok keberdosaan dan kejahatan masyarakat, dan bukan itu saja, kuasanya juga akan mengubah struktur-struktur yang menindas dan pola-pola kebiasaan yang salah dalam budaya dan

${ }^{77}$ Darrell L. Whiteman, "Contextualization: The Theory, the Gap, the Challenge," International Bulletin of Missionary Research 21, no. 1 (1997): 2-7. 
masyarakat tertentu. ${ }^{78}$ Ketiga, fungsi ekspresif. Pada fungsi ini Injil yang dikontekstualisasikan akan memiliki ekspresi-ekspresi yang unik dan signifikan di dalam budaya tertentu, sehingga kekristenan yang dihasilkan bercirikan konteks setempat. Melalui fungsi tersebut akan terbangun komunitas Kristen yang tetap setia pada warisan sejarah dan kebudayaan mereka.

\section{Injil dan Kebudayaan: Quo Vadis?}

Inti pemberitaan Injil adalah pewartaan Kristus yang tersalib, mati, bangkit dan naik ke Surga untuk membebaskan manusia dari dosa, kutuk dan penghukuman serta mendamaikan mereka dengan Allah. ${ }^{79}$ Berita ini merupakan Good News yang harus disampaikan kepada seluruh umat manusia dari berbagai latar belakang kebudayaan. ${ }^{80}$ Sifat keberdosaan manusia dan realitas penghukuman Allah atas dosa, menjadi dasar urgensinya pewarartaan Injil. Hanya melalui Injil, setiap manusia menemukan harapan yang baru, yaitu diselamatkan dari dosa dan penghukuman Allah. ${ }^{81}$

Namun demikian, iman Kristen terhadap kuasa Injil yang memulihkan manusia, tidak dapat begitu saja dipisahkan dari budaya. ${ }^{82}$ Maka untuk mengkomunikasikannya perlu mempertimbangkan kebudayaan. Usaha ini perlu dilakukan dengan cermat, mengingat kebudayaan pada dasarnya telah dicemari oleh dosa, sehingga perlu dilakukan bedah budaya untuk memilah dan memilih unsur-unsur kebudayaan yang relevan dan tidak bertentangan dengan kebenaran Injil. $^{83}$

Melalui kebudayaan, kepribadian masyarakat yang akan disapa oleh Injil akan lebih mudah untuk dikenali. Mengingat terdapat hubungan yang erat dan saling mempengaruhi antara kebudayaan, kepribadian dan masyarakat. ${ }^{84}$ Dengan mempertimbangkan budaya, pengkomunikasian Injil akan lebih sesuai dengan konteks masyarakat yang disapanya. Sehingga ketegangan antara Injil dan kebudayaan dapat dijembatani bahkan dapat menjadi media pewartaan Injil yang efektif.

${ }^{78}$ Ibid.

${ }^{79}$ David Eko Setiawan and Dwiati Yulianingsih, "Signifikansi Salib Bagi Kehidupan Manusia Dalam Teologi Paulus," FIDEI: Jurnal Teologi Sistematika dan Praktika 2, no. 2 (2019): 237-244.

${ }^{80}$ Setiawan, "Dampak Injil Bagi Transformasi Spiritual Dan Sosial,” 86.

${ }^{81}$ Ibid., 87.

${ }^{82}$ Tanudjaja, "Kontekstualisasi Sebagai Sebuah Strategi Dalam Menjalankan Misi : Sebuah Ulasan Literatur," 23.

${ }^{83}$ Ibid.

${ }^{84}$ Sutherland, Introductory Sociology, 59. 
Melalui metode kontekstualisasi, berita Injil dapat dibalut dengan kebudayaan yang sesuai dengan konteks pendengarnya. Berita Injil diwartakan berdasarkan persepsi budaya masyarakat tertentu, dengan tujuan agar Injil bukan menjadi barang asing yang susah untuk dicerna dan dipahami tetapi relevan dengan kehidupan mereka. Kontekstualisasi pada dasarnya bukanlah sinkritisme, akomodasi, atau teologi situasional. Mengapa demikian? Pertama, karena pada dasrnya sinskritisme adalah suatu usaha untuk menggabungkan dua atau lebih kepercayaan yang berbeda sehingga menciptakan suatu kepercayaan baru dengan cara merubah hal yang paling fundamental dari beberapa kepercayaan tersebut. Sedangkan kontekstualisasi bukanlah demikian, karena usaha ini tetap berorientasi kepada Alkitab dan berusaha menerjemahkan berita iman Kristen secara dynamic equivalent yang diambil secara langsung dari Alkitab ke dalam berbagai budaya di dunia. ${ }^{85}$ Kedua, berdasarkan pandangan Bavinck, akomodasi tidaklah sama dengan kontekstualisasi, dikarenakan akomodasi telah mengabaikan fakta bahwa budaya manusia telah dicemari oleh dosa, sedangkan kontekstualisasi tetap mempertimbangkan adanya pencemaran dosa pada kebudayaan manusia. Ketiga, teologi situasional bertitik tolak dari kontek sosial yang terus berubah dan berusaha menyelaraskan diri dengan kebudayaan dunia, sedangkan kontekstualisasi tetap bertitik tolak dari Alkitab serta selalu mempertimbangkan pencemaran dosa dalam kebudayaan manusia.

Kontekstualisasi merupakan proses usaha yang terus berlangsung dalam upaya dalam menjadikan Injil diterima dan dimengerti oleh si penerima dalam budaya mereka yang dinamis, baik secara politik, sosial dan ekonomi. ${ }^{86}$ Tanudjaja menyimpulkan bahwa kontekstualisasi merupakan "usaha untuk menjawab pertanyaan yang benar dalam budaya tertentu sesuai dengan Kitab Suci tanpa adanya pencemaran dari kebenaran itu sendiri." 87

\section{Simpulan}

Perjumpaan Injil dan Kebudayaan acap kali menimbulkan ketegangan. Agar pesan Injil dapat dimengerti dan diterima oleh peserta budaya tertentu, maka pewarta Injil perlu mecari metode terbaik dalam mengkomunikasikannya. Kontekstualisasi adalah usaha untuk memahami dan menganggap penting

${ }^{85}$ Charles H Kraf, "The Contextualization of Theology," Evangelical Missions Quarterly 14, no. 1 (1978): 31-36.

${ }^{86}$ Tanudjaja, "Kontekstualisasi Sebagai Sebuah Strategi Dalam Menjalankan Misi: Sebuah Ulasan Literatur," 23.

${ }^{87}$ Tanudjaja, "Kontekstualisasi Sebagai Sebuah Strategi Dalam Menjalankan Misi : Sebuah Ulasan Literatur,” 23. 
konteks khusus dari masing-masing masyarakat dan pribadi dalam istilahistilahnya sendiri dan dalam semua dimensi budaya, keagamaan, sosial, politik ekonomi serta mempertajam apa yang Injil katakan kepada orang-orang di dalam konteks tersebut. Metode ini sangat mempertimbangakan budaya, mengingat Injil dan kebudayaan adalah dua hal yang tidak dapat dipisahkan. Dengan menggunakan metode tersebut, pewarta Injil akan membungkus pesan Injil dengan budaya suatu masyarakat tertentu agar pesan tersebut tidak menjadi asing namun relevan dengan kehidupan mereka. Injil akan lebih mudah dicerna berdasarkan persepsi budaya mereka.

\section{Daftar Pustaka}

Afiah, Nur. "Kepribadian Dan Agresivitas Dalam Berbagai Budaya." Buletin Psikologi 23, no. 1 (2015): 13.

Conn, H. M. "Contextualization: A New Dimension for Cross-Cultural Hermeneutic." Evangelical Missions Quarterly 14, no. 1 (1978): 42.

Dada, Ronaldy, and Alperiana Ermin Mosooli. "Konsep Agama Suku Wana Tentang Kematian, Implikasinya Bagi Misi Kristen Di Wana." Visio Dei: Jurnal Teologi Kristen 1, no. 2 (2019): 200-221.

Gea, Ibelala. "Beritakan Injil Kepada Segala Makhluk." BIA': Jurnal Teologi dan Pendidikan Kristen Kontekstual 1, no. 1 (2018): 56-69.

Guillot, C. Kiai Sadrach: Riwayat Kristenisasi Di Jawa. Grafiti Pers., 1981.

Harun, Martin. "Perjumpaan Injil Dan Kebudayaan Dalam Kerasulan Paulus." Studia Philosophica et Theologica 16, no. 1 (2016): 1-16.

Henry, Matthew. Tafsiran Surat Roma, 1 \& 2 Korintus. Surabaya: Penerbit Momentum, 2015.

Hesselgrave, D. J. Communicating Christ Cross-Culturally : Mengomunikasikan Kristus Secara Lintas Budaya. Malang: Malang Literatur SAAT, 2004.

Kato, H. Byang. The Gospel, Cultural Context, and Religious Syncritism. Minneapolis: World Wide Publications, 1975.

Koentjaraningrat. Pengantar Ilmu Antropologi. . Jakarta: Rineke Cipta, 2000.

Kraf, Charles H. "The Contextualization of Theology." Evangelical Missions Quarterly 14, no. 1 (1978): 31-36.

Krippendorff, Klaus. Analisis Isi Pengantar Teori Dan Metodologi. Jakarta: PT. Raja Grafindo Persada, 1993.

Kuhltau, C. C. Teaching The Library Research. USA: Scarecrow Press Inc, 2020.

Loh, I. Jin, Howard A. Hatton. Pedoman Penafsiran Alkitab: Surat Paulus Yang 
Menjembatani Injil... (David E. Setiawan)

Pertama Kepada Jemaat Di Korintus. Jakarta: Lembaga Alkitab Indonesia, 2019.

Mamahit, Ferry Y. "Hermeneutika Peleburan Dua Horizon Anthony Thiselton Dan Tantangan Dari Antropologi Lintas Budaya." Veritas : Jurnal Teologi dan Pelayanan 18, no. 1 (2019): 33-46.

Mardalis. Metode Penelitian Suatu Pendekatan Proposal. Jakarta: Bumi Aksara, 1999.

Nenohai, Jear Niklas Dominggus K. "Penenerjemahan Sebagai Media

Pekabaran Injil Middelkop Ditinjau Dari Perspektif Hermenutika Hans

Georg Gadamer." Gema Teologika 3, no. 2 (2018): 101-120.

Nicholls, Bruce. J. Theological Education and Evangelization, n.d.

Panjaitan, Firman, and Hendro Siburian. "Misi Kristologi Dalam Konteks Kebudayaan.” Logia 1, no. 1 (2020): 44-61.

Partonadi, Sutarman Soediman. Sadrach's Community and Its Contextual Roots:

A Nineteenth Century Javanese Expression of Christianity. .: Rodopi, 1990.

Pasaribu, Marulak. Eksposisi Injil Sinoptik. Malang: Gandum Mas, 2005.

Peters, George W. ". Issues Confronting Evangelical Missions." Evangelical Missions Tomorrow. Pasadena: William Carey, 1977.

Roucek, Joseph Slabey, Roland L. Warren, Alexander Kuman. Sociology: An Introduction. Littlefield, Adams \& Company, 1968.

Sarinah. Ilmu Budaya Dasar. Sleman: CV Budi Utama, 2019.

Sarwono, Jonathan. Metode Penelitian Kuantitatif Dan Kualitatif. Yogyakarta: Graha Ilmu, 2006.

Setiawan, David Eko. "Dampak Injil Bagi Transformasi Spiritual Dan Sosial." BIA': Jurnal Teologi dan Pendidikan Kristen Kontekstual 2, no. 1 (2019): 83-93.

Misi Perintisan Jemaat Alkitabiah-Kontekstual. Yogyakarta: CV. Diandra Kreatif, 1997.

Setiawan, David Eko, and Dwiati Yulianingsih. "Signifikansi Salib Bagi Kehidupan Manusia Dalam Teologi Paulus." FIDEI: Jurnal Teologi Sistematika dan Praktika 2, no. 2 (2019): 227-246.

Singgih, Emanuel Gerrit. "A Postcolonial Biography of Sadrach: The Tragic Story of an Indigenous Missionary." Al-Jami'ah 53, no. 2 (2015): 367-386. Singgih, Emmanuel Gerrit. Berteologi Dalam Konteks: Pemikiran-Pemikiran Mengenai Kontekstualisasi Teologi Di Indonesia. Kanisius, 2000.

Siswanto, K. "Perjumpaan Injil Dan Tradisi Jawa Timuran Dalam Pelayanan Misi Kontekstual"." Evangelikal: Jurnal Teologi Injili dan Pembinaan 
180 Fidei: Jurnal Teologi Sistematika dan Praktika, Vol. 3, No. 2, Des. 2020

Warga Jemaat 1, no. 1 (2017): 61-66.

Soekanto, Soerjono. Sosiologi Suatu Pengantar. Jakarta: Rajawali Pers, 2009.

Sondegau, Kleopas. "Kristologi Dalam Konteks Kebudayaan Suku Migani Di Papua” 17, no. 1 (2017): 60-79.

Stevanus, Kalis. Panggilan Teragung. Yogyakarta: Penerbit Andi, 2019.

Sutherland, Robert L. Introductory Sociology. 6th ed. Chicago: J.B. Lippincott Company, 1961.

Tanudjaja, Rahmiati. "Kontekstualisasi Sebagai Sebuah Strategi Dalam Menjalankan Misi : Sebuah Ulasan Literatur." Veritas : Jurnal Teologi dan Pelayanan 1, no. 1 (2000): 19-27.

Tari, Ezra. "Teologi Tongkonan : Berteologi Dalam Konteks Budaya Toraja" 2, no. 2 (2018): 93-102.

Tomatala, Y.Y. Penginjilan Masa Kini. Penerbit Gandum Mas, 1997.

Tomatala, Yakoub. Antropologi: Dasar Pendekatan Pelayanan Lintas Budaya. Jakarta: YT Leadership Foundation, 2007.

Verkuyl, J. Etika Kristen Dan Kebudayaan. 2nd ed. Jakarta: Badan Penerbit Kristen, 1966.

Waluya, Bagja. Sosiologi: Menyelami Fenomena Sosial Di Masyarakat. PT Grafindo Media Pratama, 2007.

Whiteman, Darrell L. "Contextualization: The Theory, the Gap, the Challenge." International Bulletin of Missionary Research 21, no. 1 (1997): 2-7.

Widjaja, Fransiskus Irwan. "Papua Dan Panggilan Macedonia Di Zaman Millennium Baru." DIEGESIS: Jurnal Teologi Kharismatika 2, no. 1 (2019): 35-38.

Zaluchu, Sonny. "Penderitaan Kristus Sebagai Wujud Solidaritas Allah Kepada Manusia." DUNAMIS: Jurnal Penelitian Teologi dan Pendidikan Kristiani 2, no. 1 (2017): 61.

Zed, Mestika. Metode Peneletian Kepustakaan. Yayasan Obor Indonesia, 2004. 